\title{
CHRNA3 wt Allele
}

National Cancer Institute

\section{Source}

National Cancer Institute. CHRNA3 wt Allele. NCI Thesaurus. Code C77119.

Human CHRNA3 wild-type allele is located in the vicinity of $15 q 24$ and is approximately 28 $\mathrm{kb}$ in length. This allele, which encodes neuronal acetylcholine receptor subunit alpha-3 protein, is involved in both ion transport and ligand recognition. Mutation of the gene is associated with lung cancer type 2 and peripheral arterial occlusive disease type 2 . 